\title{
La calidad del agua: un eje clave de política pública
}

Autor:

Adrián Pedrozo Acuña Fecha de publicación: 4 de mayo de 2020
La contaminación del agua afecta la salud pública

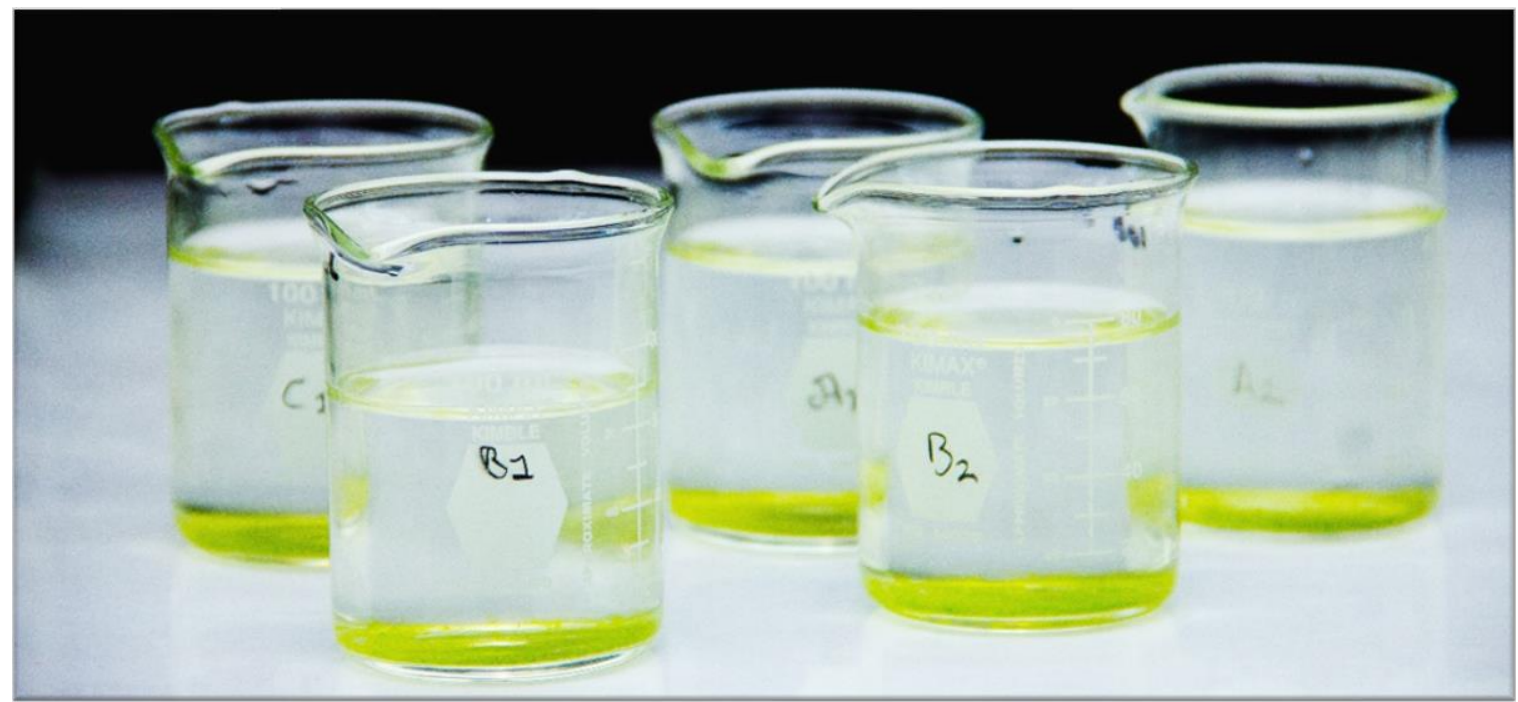

Existen pocos problemas ambientales que generen un debate tan intenso como el que suscita el de la calidad del agua.

La contaminación del agua afecta la salud pública, el ambiente y el bienestar económico de todas las naciones. Dado que los orígenes de la contaminación son diversos y su mitigación muy complicada, su política pública hace de este tema uno de los problemas ambientales más difíciles de manejar.

A pesar del progreso observado en los últimos cuarenta años, la mala calidad del agua es uno de los problemas más serios a los que se enfrenta el planeta. Datos de la Organización Mundial de la Salud indican que más del 80 \% del agua utilizada en el mundo no recibe ningún tratamiento. Existe entonces una gran necesidad de más y mejores regulaciones respecto a los límites máximos permisibles de contaminantes generados en descargas de industrias que producen sustancias tóxicas. Muchos autores reconocen que esta deficiencia en la regulación se debe a que los gobiernos tienen como prioridad un rápido desarrollo económico por encima de cualquier costo ambiental.

Por otro lado, adoptar opciones de disminución en la contaminación del agua requiere decisiones muy complicadas que implican un adecuado manejo de suelo, agua y gasto público. Por lo anterior, no es extraño ver el tema de agua limpia en las agendas políticas de prácticamente todos los países del mundo. 
Por lo general, el tamaño de las fuentes de contaminación se distingue en escalas macro (nivel sectorial) y micro (nivel individual). Por ejemplo, las descargas del drenaje y aguas no tratadas que se producen por actividades que liberan químicos tóxicos, bacterias, virus y parásitos se consideran fuentes macro. Además de estos contaminantes, elementos como el nitrógeno y el fósforo, generados por el uso de fertilizantes en granjas y zonas agrícolas, degradan la capacidad de los cuerpos de agua para sostener la vida de plantas y animales acuáticos. Estos contaminantes, junto con los desechos humanos y animales, representan los degradadores más importantes de la calidad del agua en todo el mundo.

Las estrategias para la gestión de la contaminación del agua suelen ser de dos tipos: la primera, empleada por estados que han alcanzado algún grado de sofisticación tecnológica, consiste en financiar obra pública con el propósito de eliminar desechos humanos, animales e industriales de las ciudades, de tal suerte que no haya contacto de éstos con los seres humanos; la segunda fomenta obra pública con la intención de proteger la salud humana, considerando la salud del ambiente como un alcance secundario. Sin embargo, existe una tercera aproximación que resulta de las dos primeras, cuyo objetivo es asegurar que el agua para consumo humano no esté contaminada con productos de desecho, y que considera los ríos como vías de drenaje natural. Esta visión favoreció la construcción de grandes acueductos y sistemas de abastecimiento para las ciudades que se encargan de traer aguas cristalinas de ríos y cuencas distantes. No fue sino hasta el siglo XX cuando nos dimos cuenta de la ventaja de tratar el agua y purificarla, para así proteger la vida silvestre y la calidad de nuestro medio ambiente.

La evolución de la política pública relacionada con la calidad del agua en países como Estados Unidos, Rusia, China y Francia indica que entre más avanzada sea la economía de un país y su sistema regulatorio, habrá grupos ambientales más fuertes y una mayor preocupación ciudadana por la protección del ambiente. Por lo tanto, no es raro ver a grupos de la sociedad civil local participando en la creación de regulaciones y, sobre todo, en acciones de monitoreo de la calidad del agua en los cuerpos de agua dentro de su territorio.

En contraste, en países en desarrollo, los sectores que promueven el crecimiento económico a cualquier costo ejercen más influencia sobre las decisiones ambientales, por lo que la política de la contaminación tiende a ser controlada por las industrias y los grandes grupos agroalimentarios. Por si esto fuera poco, los controles tecnológicos de contaminación tienden a ser menos avanzados e insuficientemente operacionalizados debido a restricciones de gasto. De hecho, este tipo de desventaja se encuentra también a una escala subnacional dentro de los países desarrollados (p.ej. Caso Flint, EUA). Esta situación crea una marcada desigualdad en la repartición de impactos al interior de los países.

Existen tres hechos generales en torno a la evolución en la gobernanza de la contaminación del agua: 1) La calidad del agua sufre cuando hay baja inversión en los controles ambientales, poco esfuerzo proactivo en la prevención de fuentes de contaminación y abandono de sistemas de observación y monitoreo, además de la poca inversión en sistemas de tratamiento; 2) El crecimiento poblacional y el desarrollo económico incrementan la presión sobre suelo y agua, con el cambio de dietas hacia carnes y lácteos. El problema de la calidad del agua no solo se refiere a falta de inversión y voluntad política, sino que es un problema de alineación de inversiones en calidad del agua con el fin de alcanzar un mayor crecimiento económico. 3) A pesar del progreso en la atención de las causas flagrantes de la contaminación del agua, todas las naciones del planeta enfrentan el reto del cambio en las prácticas establecidas, pues persiste una pesada inercia y un discurso anquilosado en la manera de enfrentar el problema (p.ej. no hay recursos, no hay capacidad).

Prevalece un debate abierto sobre las mejores prácticas para aliviar la contaminación del agua. Algunos proponen que la calidad del agua debe estar protegida por medio de reparación, restauración y 
PERSPECTIVAS IMTA (0)

$\mathrm{N}^{\circ} .3,2020$

Autor: Adrián Pedrozo Acuña

DOI: doi.org/10.24850/b-imta-perspectivas-2020-03

mitigación definidas a través de normas y marcos jurídicos muy estrictos. Otros proponen incentivos económicos para utilizar esquemas con base en valores límite de concentraciones en combinación con estrategias de desarrollo de bajo impacto (LID, por sus siglas en inglés). Hay que recordar que lo que está en juego es la relación entre el agua y los seres humanos, lo que se conoce como metabolismo hidrosocial. En cualquier caso, es momento de involucrar a la sociedad en la creación y seguimiento de las nuevas normas, cuyo propósito es cuidar la salud del medio ambiente y la nuestra propia. 